\title{
Methionine supply during the periparturient period enhances insulin signaling, amino acid transporters, and mechanistic target of rapamycin pathway proteins in adipose tissue of Holstein cows
}

\author{
Y. Liang, ${ }^{1}$ F. Batistel, ${ }^{1 *}$ C. Parys,${ }^{2}$ and J. J. Loor ${ }^{1} \dagger$ \\ ${ }^{1}$ Department of Animal Sciences and Division of Nutritional Sciences, University of Illinois, Urbana 61801 \\ ${ }^{2}$ Evonik Nutrition \& Care GmbH, Hanau-Wolfgang, 63457, Germany
}

\section{ABSTRACT}

Enhanced postruminal supply of Met during the periparturient period increases dry matter intake and milk yield. In nonruminants, adipose tissue is responsive to AA supply, and can use AA as fuels or for protein synthesis regulated in part via insulin and mechanistic target of rapamycin (mTOR) signaling. Whether enhancing supply of Met has an effect on insulin and mTOR pathways in adipose tissue in peripartal cows is unknown. Multiparous Holstein cows were assigned from -28 to $60 \mathrm{~d}$ relative to parturition to a basal diet (control; $1.47 \mathrm{Mcal} / \mathrm{kg}$ of dry matter and $15.3 \%$ crude protein prepartum; $1.67 \mathrm{Mcal} / \mathrm{kg}$ and $17.7 \%$ crude protein postpartum) or the control plus ethylcellulose rumen-protected Met (RPM). The RPM was fed individually at a rate of $0.09 \%$ of dry matter intake prepartum and $0.10 \%$ postpartum. Subcutaneous adipose tissue harvested at $-10,10$, and $30 \mathrm{~d}$ relative to parturition (days in milk) was used for quantitative PCR and Western blotting. A glucose tolerance test was performed at -12 and $12 \mathrm{~d}$ in milk to evaluate insulin sensitivity. Area under the curve for glucose in the pre- and postpartum tended to be smaller in cows fed Met. Enhanced Met supply led to greater overall mRNA abundance of Gln (SLC38A1), Glu (SLC1A1), L-type AA (Met, Leu, Val, Phe; SLC3A2), small zwitterionic $\alpha$-AA (SLC36A1), and neutral AA (SLC1A5) transporters. Abundance of AKT1, RPS6KB1, and EIF $4 E B P 1$ was also upregulated in response to Met. $A$ diet $\times$ day interaction was observed for protein abundance of insulin receptor due to Met cows having lower values at $30 \mathrm{~d}$ postpartum compared with controls. The diet $\times$ day interaction was significant for hormone-sensitive lipase due to Met cows having greater abundance at $10 \mathrm{~d}$ postpartum compared with controls.

Received September 22, 2018

Accepted January 11, 2019.

*Current address: Department of Animal, Dairy and Veterinary Sciences, Utah State University, Logan, UT 84322-4815.

†Corresponding author: jloor@illinois.edu
Enhanced Met supply upregulated protein abundance of insulin-responsive proteins phosphorylated (p)-AKT, peroxisome proliferator-activated receptor gamma, and fatty acid synthase. Overall abundance of solute carrier family 2 member 4 tended to be greater in cows fed Met. A diet $\times$ day interaction was observed for mTOR protein abundance due to greater values for RPM cows at $30 \mathrm{~d}$ postpartum compared with controls. Enhanced RPM supply upregulated overall protein abundance of solute carrier family 1 member 3 , p-mTOR, and ribosomal protein S6. Overall, data indicate that mTOR and insulin signaling pathways in adipose tissue adapt to the change in physiologic state during the periparturient period. Further studies should be done to clarify whether the activation of p-AKT or increased availability of AA leads to the activation of mTOR.

Key words: amino acid transporter, mechanistic target of rapamycin, insulin response, transition period

\section{INTRODUCTION}

The periparturient or "transition" period is the most challenging of the production cycle of dairy cows. During this period cows undergo great immunometabolic changes and are more susceptible to a heightened state of oxidative stress and inflammation (Loor et al., 2013; Sordillo and Raphael, 2013; Osorio et al., 2014b). A state of insulin resistance (Sordillo and Raphael, 2013; De Koster et al., 2018) designed to limit glucose utilization by tissues such as adipose and muscle (Zhai et al., 2010) also characterizes the transition period. These endocrine and physiologic adaptations are now considered components of homeorhesis, allowing the mammary gland to have priority over nutrient utilization for milk synthesis (Vailati-Riboni et al., 2015; Zhou et al., 2016a). Despite the importance of insulin signaling in adipose tissue, few studies (e.g., Zachut et al., 2013) have addressed the concerted longitudinal adaptations of insulin-sensitive components including the insulin receptor (INSR), intracellular kinases (e.g., insulin receptor 1, IRS1; AKT serine/threonine kinase, AKT), 
glucose transporters (solute carrier family 2 member 4; SLC2A4), transcription regulators (e.g., peroxisome proliferator-activated receptor gamma, PPARG), and enzyme targets (e.g., fatty acid synthase, FASN).

Although it is well established that adipose tissue is a major organ for glucose and lipid metabolism in mammalian species, and hence responsive to insulin (De Koster and Opsomer, 2013), its role in systemic protein and AA metabolism in dairy cows is not well known. For instance, feeding $20 \mathrm{~g} / \mathrm{d}$ of methionine hydroxyl analog to diets containing 11 or $14 \% \mathrm{CP}$ between -14 through $60 \mathrm{~d}$ around parturition resulted in lower body protein loss (Phillips et al., 2003). Furthermore, CP alone enhanced fat and body protein gain between 60 to $120 \mathrm{~d}$ postpartum. Although the exact mechanisms for those responses were not studied, research in humans and rodents indicates that adipose tissue can use AA such as Met and branched-chain amino acids (BCAA; Feller and Feist, 1963; Badoud et al., 2014). Methionine is the first-limiting AA in dairy cows, and feeding rumen-protected methionine (RPM) contributes to more efficient utilization of this and other AA for milk synthesis (Schwab and Broderick, 2017). Besides serving as backbone for protein synthesis, BCAA (leucine, isoleucine, and valine) are EAA (Lu et al., 2013) with the capacity to regulate the activity of mechanistic target of rapamycin ( $\mathbf{m T O R}$ ), which controls protein synthesis and cell growth (Lynch and Adams, 2014).

Obesity research in monogastrics indicated a positive association between circulating BCAA and insulin resistance (Newgard et al., 2009; McCormack et al., 2013). Not only can adipose tissue catabolize BCAA in vivo, but also can help buffer circulating BCAA levels via the regulation of enzymes (Herman et al., 2010) such as branched-chain $\alpha$-keto acid dehydrogenase kinase (BCKDK). This enzyme is key in controlling flux through the branched-chain $\alpha$-keto acid dehydrogenase complex, which is the rate-limiting step for BCAA catabolism (Shimomura et al., 2001). Although mechanistic aspects of AA metabolism by adipose tissue in dairy cows is in its infancy, the concerted evaluation of AA transporters and key controls of AA signaling (e.g., mTOR pathway) could shed light on the relevance of nutritional management during the transition period in the context of adipose tissue function and remodeling.

The objective of this study was to use adipose tissue samples from control and RPM-fed cows in the study of Batistel et al. (2017b) to evaluate changes in mRNA and protein abundance of key AA transporters and various components of the mTOR and insulin signaling pathways during the transition period. Our general hypothesis was that enhanced RPM supply activates mTOR and dampens insulin resistance in s.c. adipose tissue.

\section{MATERIALS AND METHODS}

\section{Experimental Design and Treatment}

The University of Illinois Institutional Animal Care and Use Committee (Urbana; protocol \#14270) approved all procedures involving animals for the current study. Details of the experimental design have been reported previously (Batistel et al., 2017b). Briefly, 60 multiparous Holstein cows per treatment were used in a randomized, complete, balanced block design experiment. Cows were fed a basal control (control) diet without additional Met or the control plus ethylcellulose RPM (Met; Mepron, Evonik Nutrition and Care Gmbh, Hanau-Wolfgang, Germany). The RPM was top dressed on the TMR for each cow in the Met group from -28 to $60 \mathrm{~d}$ relative to parturition at a rate of $0.09 \%$ (prepartum) and $0.10 \%$ (postpartum) of the DMI of the previous day to achieve a Lys:Met ratio of 2.8:1. From -45 to -29 d relative to parturition, all cows were fed the same diet without Met. Diets were mixed daily using a tumble mixer. The ingredient and chemical composition of the diets were reported previously (Batistel et al., 2017b). Diets were formulated to meet cow-predicted requirements according to the NRC (2001).

\section{Glucose Tolerance Test}

On $\mathrm{d}-12$ and 12 relative to expected calving date, 10 cows in the control group and 10 in the Met group received a glucose tolerance test (GTT) while restrained in a squeeze chute, approximately $2 \mathrm{~h}$ after feeding. A solution of $50 \%$ glucose (Dextrose $50 \%$, Agri Laboratories Ltd., St. Joseph, IL) was administrated at $0.25 \mathrm{~g} / \mathrm{kg}$ of BW with an intravenous set (PBS Animal Health, Massillon, $\mathrm{OH}$ ) and a disposable 14-gauge $\times$ $3.8 \mathrm{~cm}$ needle (Tyco Healthcare Group LP, Mansfield, MA) for jugular vein access. Cows were restrained in a squeeze chute and blood samples $(20 \mathrm{~mL})$ were obtained by puncture of the coccygeal vein or artery with 20-gauge $\times 2.5$-cm needles (Becton Dickinson and Company, Franklin Lakes, NJ) at $-15,-10,-5,5,10$, $15,30,60$, and 120 min relative to administration of glucose. Glucose concentration was measured using a glucose oxidase method (PGO Enzyme Product No. P7119; Sigma Chemical Co., St. Louis, MO). Intra- and interassay coefficients of variation were 5.1 and $8.5 \%$, respectively.

\section{Calculations of Plasma Biomarkers and GTT}

Basal glucose concentrations (before GTT) were calculated averaging the concentrations at 15, 10, and 5 
min before GTT. Peak, mean, and nadir concentrations for glucose were determined with the concentration values at 5, 10, 15, 30, 60, and 120 min after GTT. The areas under the curve of glucose (AUC) during the 120 min after GTT were calculated (after correcting for baseline) using the trapezoidal method and actual concentration values as described previously (Cardoso et al., 2011).

\section{Daily Plasma Insulin Concentration}

Blood samples from the same 7 cows in the control and Met groups used for biopsies were harvested via coccygeal venipuncture before feeding using evacuated tubes containing lithium heparin (Batistel et al., 2017b). Plasma was obtained by centrifugation at 2,000 $\times g$ for 30 min at $4^{\circ} \mathrm{C}$ and preserved at $-80^{\circ} \mathrm{C}$ until later analysis. Insulin concentration in plasma was determined using a bovine-specific commercial ELISA kit (catalog no. 10-1201-01, Mercodia). Intra- and interassay coefficients of variation were 12.5 and $14.8 \%$, respectively.

\section{Adipose Tissue Biopsies}

Seven cows from the Met group and 7 cows from the control were used for adipose biopsies. These cows were selected based on actual days receiving diets prepartum $(28 \pm 3 \mathrm{~d})$, absence of clinical disorders, and all had the full set of biopsies. Tissue was harvested from the tail head (alternating between the right and left tail head region) at $-10( \pm 3 \mathrm{~d}), 10$, and $30 \mathrm{~d}$ relative to parturition according to previous procedures from our laboratory (Ji et al., 2012). Upon collection, adipose tissue was immediately placed in screw-capped, microcentrifuge tubes, snap-frozen in liquid nitrogen, and preserved at $-80^{\circ} \mathrm{C}$ until further analysis. Health was monitored for $7 \mathrm{~d}$ after surgery. Surgical clips were removed after $7 \mathrm{~d}$ postbiopsy. All biopsies were harvested at approximately $0800 \mathrm{~h}$.

\section{RNA Isolation, cDNA Synthesis, and Quantitative PCR}

Total RNA was isolated from $200 \mathrm{mg}$ of adipose tissue using the miRNeasy kit (Qiagen, Hilden, Germany) according to the manufacturer's protocols. The RNA samples were digested with DNaseI and quantification was assessed using a NanoDrop ND-1000 spectrophotometer (Thermo Fisher Scientific, Waltham, MA). The quality of RNA samples was measured using an Agilent 2100 Bioanalyzer (Agilent Technologies, Santa Clara, CA). The quantitative PCR was conducted as described previously (Osorio et al., 2014a). Previously validated internal controls for adipose tissue were ribosomal protein S9 (RPS9), glyceraldehyde-3-phosphate dehydrogenase $(G A P D H)$, and $\beta$-actin $(A C T B$; VailatiRiboni et al., 2015, 2016, 2017). Gene symbols and names are presented in Table 1. Quantitative PCR performance and primer information are included in Supplemental Table S1 (https://doi.org/10.3168/jds .2018-15738).

\section{Western Blot Analysis}

Total protein was extracted from $100 \mathrm{mg}$ of adipose tissue according to a published procedure from our laboratory (Batistel et al., 2017a). The concentration of total protein was determined using a NanoDrop ND1000 (Thermo Fisher Scientific). Protein samples were denatured by heating at $100^{\circ} \mathrm{C}$ for 5 min before loading $75 \mu \mathrm{g}$ of protein into each lane of a 4 to $20 \%$ SDS-PAGE gel (catalog no. 4561096, Bio-Rad, Hercules, CA). Reactions were run for $10 \mathrm{~min}$ at $180 \mathrm{~V}$, and then for 45 to $60 \mathrm{~min}$ at $110 \mathrm{~V}$. After activating a polyvinylidene fluoride membrane (catalog no. 1620261, Bio-Rad) with methanol for $1 \mathrm{~min}$, the protein sample was transferred to the membrane in a Trans-Blot SD Semi-Dry Electrophoretic Transfer Cell (catalog no. 170-3940, Bio-Rad). Membranes were then blocked in $1 \times$ Trisbuffered saline $(1 \times$ TBST) containing $5 \%$ nonfat milk for $2 \mathrm{~h}$ at room temperature. The membranes were then incubated in $1 \times$ TBST containing primary antibodies to mTOR, phospho-mTOR (Ser2448), AKT, phosphoAKT (Ser473), INSR, SLC2A4 (formerly GLUT4), phospho-4-EBP (Thr37/46), phospho-EEF2 (Thr56), SLC3A1, SCL38A1, SLC1A5, BCKDK, RPS6, phospho-RPS6 (Ser235/236), FASN, LIPE (formerly HSL), phospho-LIPE (Ser563), PPARG, and IRS1 overnight at $4^{\circ} \mathrm{C}$. Additional information about dilution ratios and vendors is reported in Supplemental Table S2 (https: //doi.org/10.3168/jds.2018-15738). The membranes were washed 6 times with $1 \times$ TBST and incubated with anti-rabbit HRP-conjugated secondary antibodies (catalog no. ab6721, Abcam, Cambridge, UK) for $1 \mathrm{~h}$ at room temperature. Subsequently, the membranes were then washed 6 times with $1 \times$ TBST and then incubated with ECL reagent (catalog no. 170-5060, Bio-Rad) for 3 min in the dark prior image acquisition. $\beta$-Actin (catalog no. 4967S, Cell Signaling Technology, Danvers, MA) was used as the internal control. Images were acquired using the ChemiDOC MP Imaging System (Bio-Rad). The intensities of the bands were measured with Image-Pro Plus 6.0 software (Media Cybernetics Inc., Rockville, MD). Relative abundance of target proteins was normalized using $\beta$-actin. 


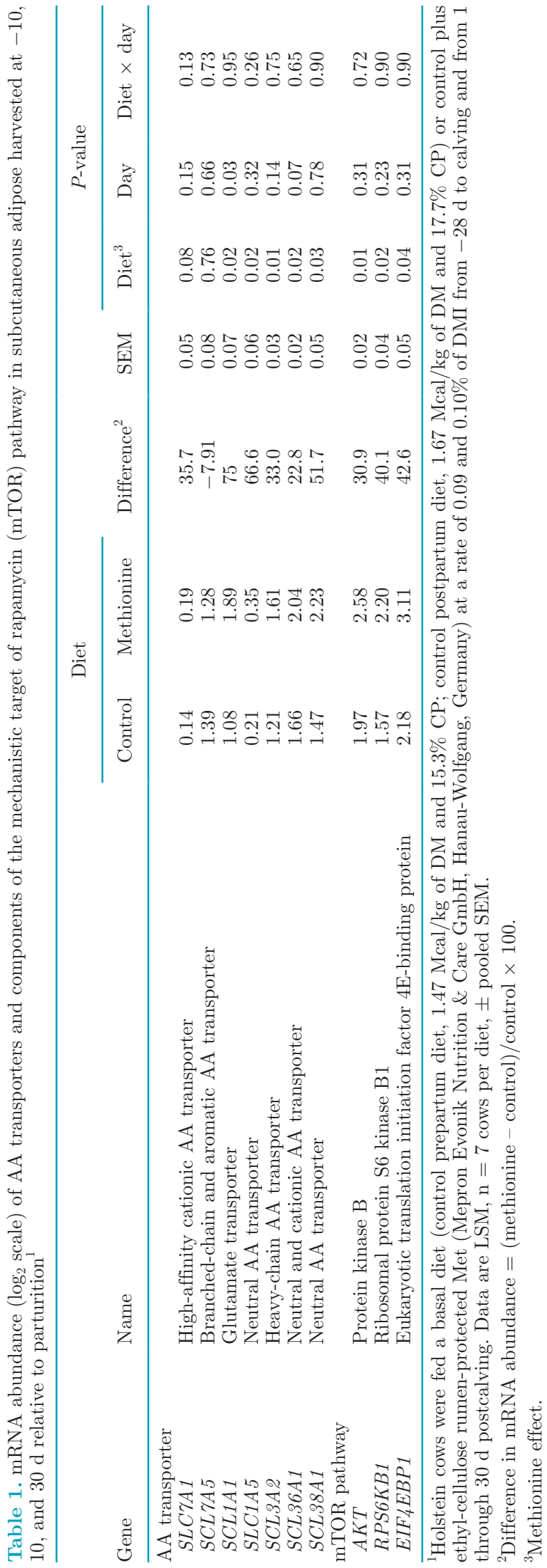

\section{Statistical Analysis}

The data were analyzed using the MIXED procedure of SAS v.9.4 (SAS Institute Inc., Cary, NC) according to the following model with repeated measures:

$$
Y_{j l}=\mu+M_{j}+T_{l}+M T_{j l}+e_{j l},
$$

where $Y_{j l}=$ dependent, continuous variable, $\mu=$ overall mean, $M_{j}=$ fixed effect of treatment $(j=$ control vs. Met), $T_{l}=$ fixed effect of time (day, $-10,10$, and $30 \mathrm{~d}$ ), $M T_{j l}=$ interaction between treatment and time, and $e_{j l}$ $=$ residual error. Cow, nested within treatment, was the random effect. The Kenward-Roger statement was used for computing the denominator degrees of freedom. The covariance structure of the repeated measurements was spatial power $[\mathrm{SP}(\mathrm{POW})]$. When the interaction was significant, least squares means separation between and within time points was performed using the PDIFF statement with Tukey adjustment. Normality of the residuals was checked with normal probability and box plots, and homogeneity of variances was checked with plots of residuals versus predicted values. The model to analyze area under the curve (AUC) of glucose contained the fixed effect of treatment, time, and their interaction (diet $\times$ day). Time (min) was specified as repeated with cow as subject. Concentrations before GTT were used as covariates when analyzing concentrations over time. The spatial power (SP) covariance structure was used because of the unequally spaced data points. Significance was determined at $P \leq 0.05$ and tendencies at $P \leq 0.10$.

\section{RESULTS}

\section{GTT and Plasma Insulin}

In the prepartum, after the GTT Met cows had greater basal concentration and maximum concentration of glucose in plasma $(P<0.05$; Table 2$)$. In addition, Met cows tended $(0.05<P \leq 0.10)$ to have smaller AUC for glucose and shorter time to baseline. In the postpartum, the AUC for glucose after the GTT tended $(P=0.09)$ to be lower in Met cows. Although no effect of diet was detected, insulin concentration decreased $(P$ $<0.05)$ significantly after parturition (Figure 1).

\section{mRNA Abundance}

Main effects of diet, time, and interactions are reported in Table 1 . The diet $\times$ day interaction was not significant $(P>0.05)$ for any gene measured. Among the 7 AA transporters measured, enhanced Met supply led to greater mRNA abundance of Gln (SLC38A1), 
Table 2. Plasma concentrations of glucose before (basal) and during a glucose tolerance test at $-12 \mathrm{~d}$ prepartum and $12 \mathrm{~d}$ postpartum ${ }^{1}$

\begin{tabular}{|c|c|c|c|c|}
\hline \multirow[b]{2}{*}{ Item } & \multicolumn{2}{|c|}{ Diet } & \multirow[b]{2}{*}{ SEM } & \multirow[b]{2}{*}{$P$-value } \\
\hline & Control & Methionine & & \\
\hline \multicolumn{5}{|l|}{ Prepartum } \\
\hline \multicolumn{5}{|l|}{ Glucose } \\
\hline Basal concentration, mg/dL & 43.1 & 46.9 & 1.85 & 0.02 \\
\hline Maximum concentration, $\mathrm{mg} / \mathrm{dL}$ & 161 & 172 & 4.38 & 0.03 \\
\hline Time to baseline, $\min$ & 75.2 & 67.9 & 3.93 & 0.07 \\
\hline $\mathrm{AUC},{ }^{2} \min \times \mathrm{mg} / \mathrm{dL}$ & 3,348 & 2,845 & 251 & 0.10 \\
\hline \multicolumn{5}{|l|}{ Postpartum } \\
\hline \multicolumn{5}{|l|}{ Glucose } \\
\hline Basal concentration, mg/dL & 38.9 & 40.1 & 1.85 & 0.45 \\
\hline Maximum concentration, $\mathrm{mg} / \mathrm{dL}$ & 152 & 147 & 5.23 & 0.39 \\
\hline Time to baseline, $\min$ & 59.3 & 55.4 & 3.54 & 0.29 \\
\hline $\mathrm{AUC}, \mathrm{mg} / \mathrm{dL} \times \min$ & 3,485 & 3,095 & 211 & 0.09 \\
\hline
\end{tabular}

${ }^{1}$ Holstein cows were fed a basal diet [control prepartum diet, $1.47 \mathrm{Mcal} / \mathrm{kg}$ of DM and $15.3 \% \mathrm{CP}$; control postpartum diet, $1.67 \mathrm{Mcal} / \mathrm{kg}$ of DM and $17.7 \% \mathrm{CP}$ ] or control plus ethyl-cellulose rumen-protected Met (Mepron, Evonik Nutrition \& Care GmbH, Hanau-Wolfgang, Germany) at a rate of 0.09 and $0.10 \%$ of DMI from -28 to calving and from 1 through $30 \mathrm{~d}$ postcalving. Data are LSM, $\mathrm{n}=10$ cows per diet, \pm pooled SEM.

${ }^{2} \mathrm{AUC}=$ area under the curve.

Glu (SLC1A1), L-type AA (Met, Leu, Val, Phe; $S L$ C3A2), small zwitterionic $\alpha$-AA (SLC36A1), and neutral AA $(S L C 1 A 5)$ transporters $(P<0.05)$. Abundance of $A K T 1$ and the mTOR-related genes RPS6KB1 and EIF $4 E B P 1$ was also upregulated $(P<0.05)$ in Met cows compared with controls (Table 1 ).

\section{Protein Abundance}

Insulin Signaling. Main effects of diet, time, and interactions are reported in Figures 2, 3, and 4. A diet $\times$ day interaction $(P<0.05)$ was observed for INSR in part due to Met cows having lower $(P<0.05)$ abundance at $30 \mathrm{~d}$ relative to parturition compared with controls (Figure 2). The treatment $\times$ time interaction was also significant $(P<0.05)$ for hormone-sensitive lipase (LIPE) due to Met cows having greater $(P<$ 0.05 ) abundance at $10 \mathrm{~d}$ postpartum compared with controls (Figure 2). Enhanced RPM supply led to greater overall protein abundance of phosphorylated (p)-AKT, PPARG, SLC2A4, and FASN $(P<0.05$; Figure 2). The abundance of p-LIPE and IRS1 could not be detected with the antibodies used.

Transporters of $A A$ and mTOR Pathway. The diet $\times$ day interaction was significant $(P<0.05)$ for mTOR due in part to Met cows having greater $(P<$ 0.05 ) abundance at $30 \mathrm{~d}$ postpartum compared with controls (Figure 4). The diet $\times$ day interaction was significant for protein abundance of p-EEF2 $(P<0.05)$ due to a lower abundance $(P<0.05)$ at $10 \mathrm{~d}$ postpartum in Met cows compared with controls (Figure 4). Enhanced Met supply upregulated overall abundance of SLC1A3 (Figure 3), p-mTOR, and ribosomal protein S6 (RPS6; $P<0.05$; Figure 4).

\section{DISCUSSION}

Recent studies feeding RPM to enhance Met supply during the periparturient period have underscored the importance of this AA for milk protein synthesis but also for synthesis of antioxidants such as glutathione (Osorio et al., 2014a; Zhou et al., 2016a, 2018; Batistel et al., 2017b, 2018). The decrease in plasma insulin after parturition is well documented (De Koster et al.,

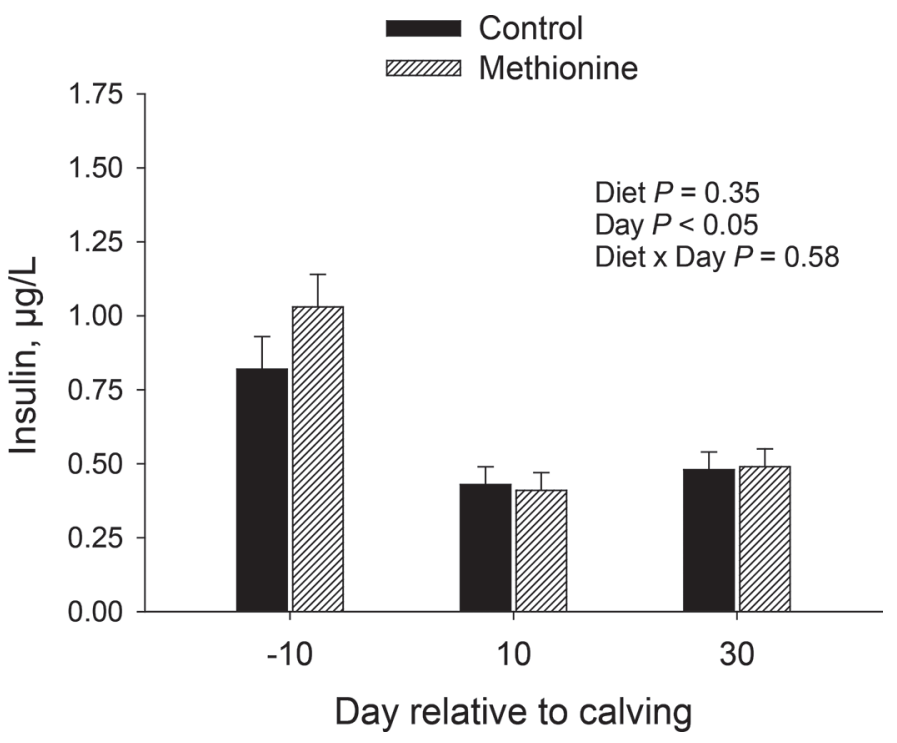

Figure 1. Insulin concentration in plasma from Holstein cows fed a basal diet (control prepartum diet, $1.47 \mathrm{Mcal} / \mathrm{kg}$ of DM and $15.3 \%$ $\mathrm{CP}$; control postpartum diet, $1.67 \mathrm{Mcal} / \mathrm{kg}$ of DM and $17.7 \% \mathrm{CP}$ ) or control plus ethyl-cellulose rumen-protected Met at a rate of 0.09 and $0.10 \%$ of DMI from $-28 \mathrm{~d}$ to calving and from 1 through $30 \mathrm{~d}$ postcalving. Data are LSM, $\mathrm{n}=7$ cows per diet, \pm pooled SEM. 


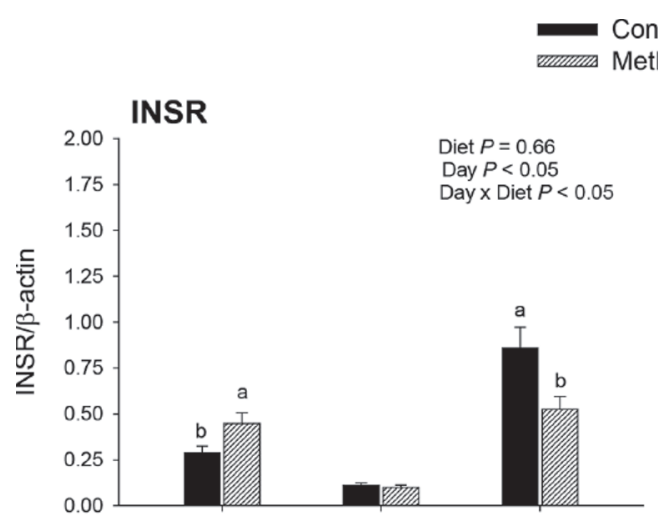

Control

Methionine
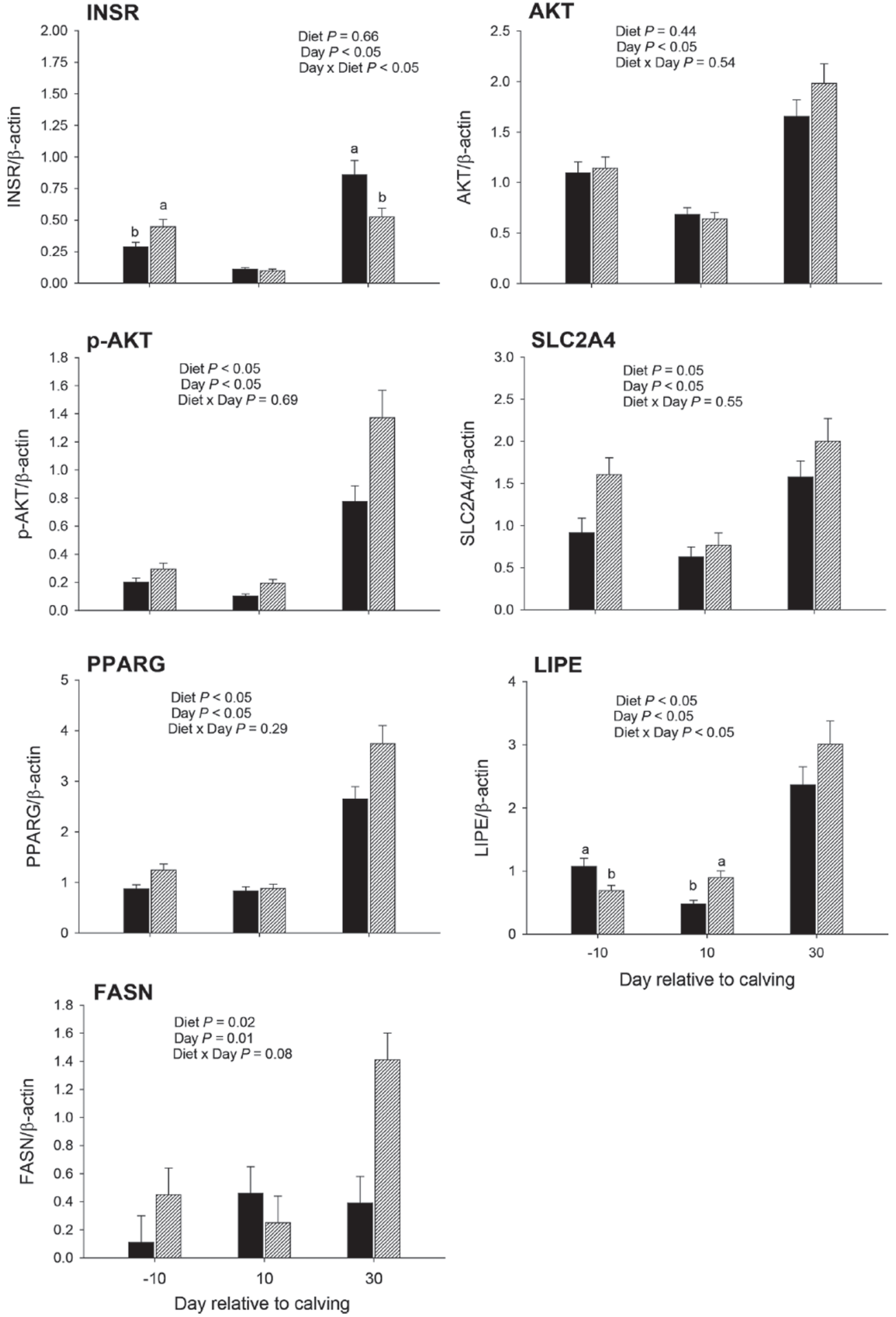

Figure 2. Protein abundance (relative to $\beta$-actin) of insulin signaling pathway components AKT serine/threonine kinase (AKT), p-AKT, insulin receptor (INSR), and solute carrier family 2 member 4 (SLC2A4), and lipid metabolism targets hormone-sensitive lipase (LIPE), fatty acid synthase (FASN), and peroxisome proliferator-activated receptor gamma (PPARG) in s.c. adipose tissue harvested at -10, 10, and 30 d relative to parturition. Holstein cows were fed a basal diet (control prepartum diet, $1.47 \mathrm{Mcal} / \mathrm{kg}$ of DM and $15.3 \%$ CP; control postpartum diet, $1.67 \mathrm{Mcal} / \mathrm{kg}$ of $\mathrm{DM}$ and $17.7 \% \mathrm{CP}$ ) or control plus ethyl-cellulose rumen-protected Met at a rate of 0.09 and $0.10 \%$ of DMI from $-28 \mathrm{~d}$ to calving and from 1 through $30 \mathrm{~d}$ postcalving. Data are LSM, $\mathrm{n}=7$ cows per diet, \pm pooled SEM. Means with different letters (a,b) differ $($ diet $\times$ day, $P \leq 0.05)$. 

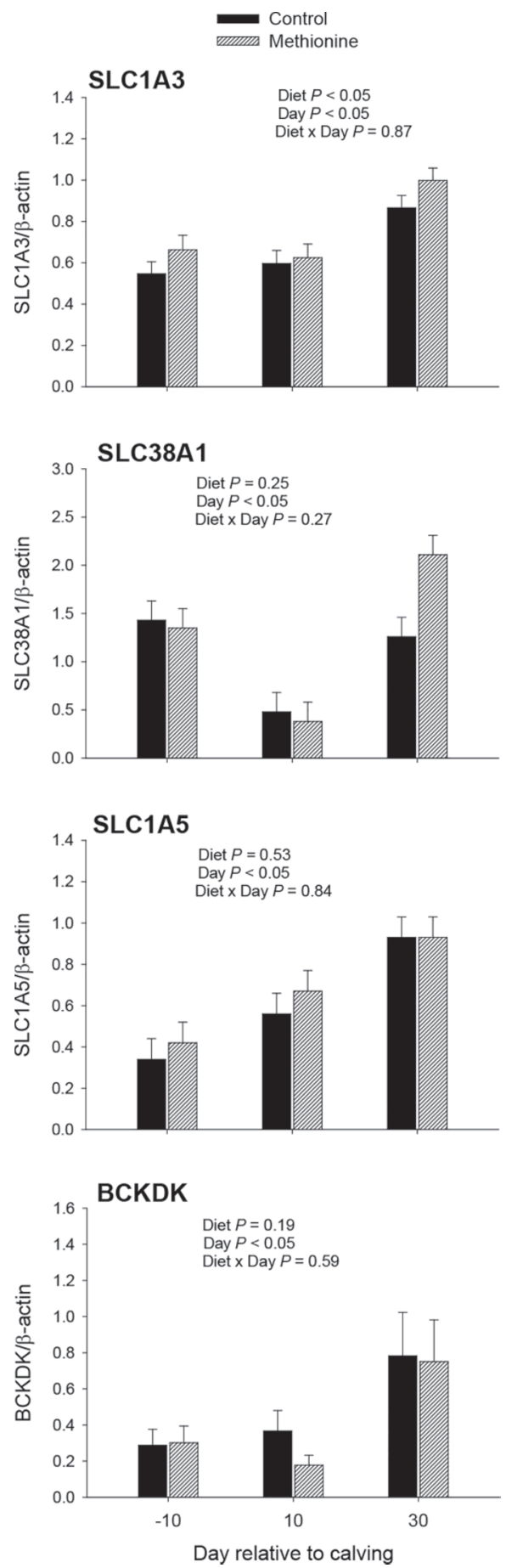

Figure 3. Protein abundance (relative to $\beta$-actin) of AA transporters solute carrier family 1 member 3 (SLC1A3), solute carrier family 38 member 1 (SLC38A1), and solute carrier family 1 member 5 (SLC1A5) and the rate-limiting enzyme for branched-chain amino acid catabolism branched-chain $\alpha$-keto acid dehydrogenase kinase (BCKDK) in s.c. adipose tissue harvested at $-10,10$, and $30 \mathrm{~d}$ relative to parturition. Holstein cows were fed a basal diet (control prepartum diet, $1.47 \mathrm{Mcal} / \mathrm{kg}$ of $\mathrm{DM}$ and $15.3 \% \mathrm{CP}$; control postpartum diet, $1.67 \mathrm{Mcal} / \mathrm{kg}$ of $\mathrm{DM}$ and $17.7 \% \mathrm{CP}$ ) or control plus ethyl-cellulose rumen-protected Met at a rate of 0.09 and $0.10 \%$ of DMI from $-28 \mathrm{~d}$ to calving and from 1 through $30 \mathrm{~d}$ postcalving. Data are LSM, $\mathrm{n}=7$ cows per diet, \pm pooled SEM.
2018) and explains in part the typical surge in plasma fatty acids as detected in the cows used in this study (Batistel et al., 2018). Clearly, despite the greater rate of DMI in cows fed Met compared with controls (Batistel et al., 2017b), adipose tissue responded according to the homeorhetic theory (Bauman and Currie, 1980).

Insulin binding to the INSR triggers a cascade of events in which phosphorylation of AKT enhances INSR phosphorylation followed by activation of IRS1 with the end result of enhancing the movement of SLC2A4 to the plasma membrane to allow for uptake of glucose (Pessin and Saltiel, 2000). Clearly, one of the key homeorhetic adaptations during the peripartal period is a decrease in insulin sensitivity of adipose and muscle to prioritize mammary utilization of insulinsensitive nutrients such as glucose and AA (Bauman and Currie, 1980). A side effect of insulin insensitivity is the catabolism of fat depots and skeletal muscle, with the former often exacerbating the capacity of the liver to fully metabolize fatty acids and rendering cows more susceptible to fatty liver and ketosis (Bell and Bauman, 1997).

In a previous study dealing with s.c. adipose tissue, the phosphorylation level of AKT under conditions of a GTT and BW loss after calving were used to classify periparturient cows into insulin resistant or insulin sensitive subgroups (Zachut et al., 2013). Data established an association between p-AKT status and degree of BW loss such that greater p-AKT after a glucose tolerance challenge was associated with a lower degree of BW loss (i.e., a response reflective of insulin sensitivity; Zachut et al., 2013). In a follow-up study with tissue from those subgroups, proteomics analysis revealed that out of a total of 586 proteins identified a subset of $18.9 \%$ (111) differed in insulin-resistant versus insulin-sensitive tissue and most were upregulated (Zachut, 2015). Bioinformatics analysis of those proteins identified as the most relevant pathways gluconeogenesis and glycolysis, 14-3-3 mediated signaling, tricarboxylic acid cycle, and extracellular signal-regulated kinase/mitogen-activated protein kinase signaling with accumulation of lipid, release of lipid, and lipolysis as the most relevant lipid-related functions. It is also noteworthy that between late prepartum and soon after calving, the vast majority of proteins identified had a decrease in abundance regardless of insulin sensitivity status (Zachut, 2015).

Although previous proteomics data demonstrated a clear change in the adipose tissue proteome and p-AKT status, the postpartum sample was harvested at 3 to 5 DIM, which certainly would not have captured the physiological dynamics of the adipose tissue during the entire transition period (i.e., first 30 DIM; McNamara et al., 1995; Khan et al., 2013). The present study 

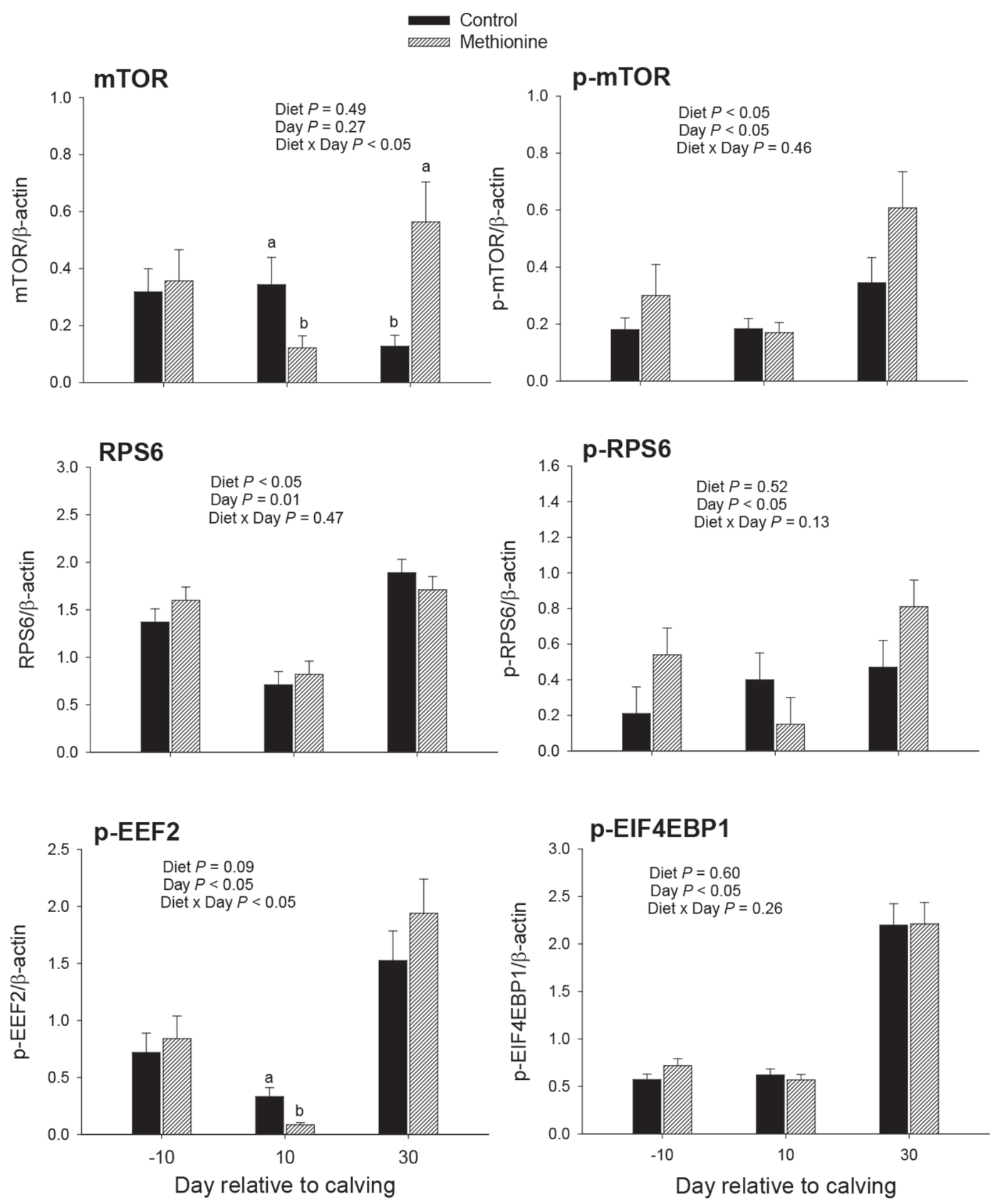

Figure 4. Protein abundance (relative to $\beta$-actin) of the mechanistic target of rapamycin (mTOR) pathway components mTOR, phosphorylated (p)-mTOR, eukaryotic initiation factor 4E-binding protein (p-EIF4EBP1), eukaryotic elongation factor 2 (p-EEF2), ribosomal protein S6 (RPS6), and p-RPS6 in s.c. adipose tissue harvested at -10, 10, and $30 \mathrm{~d}$ relative to parturition. Holstein cows were fed a basal diet (control prepartum diet, $1.47 \mathrm{Mcal} / \mathrm{kg}$ of DM and $15.3 \% \mathrm{CP}$; control postpartum diet, $1.67 \mathrm{Mcal} / \mathrm{kg}$ of DM and $17.7 \% \mathrm{CP}$ ) or control plus ethyl-cellulose rumen-protected Met at a rate of 0.09 and $0.10 \%$ of DMI from $-28 \mathrm{~d}$ to calving and from 1 through $30 \mathrm{~d}$ postcalving. Data are LSM, $\mathrm{n}=7$ cows per diet, \pm pooled SEM. Means with different letters (a,b) differ (diet $\times$ day, $P \leq 0.05$ ).

corroborates the decrease in abundance of plasma insulin along with INSR, AKT, p-AKT, and SLC2A4 soon after parturition, all of which are associated with insulin signaling in adipose. We also extend the work of Zachut et al. (2013) and Zachut (2015) to include data demonstrating the adipose response to supply of dietary Met across the periparturient period. The tendency for lower glucose AUC pre- and postpartum along with the greater overall abundance of p-AKT, SLC2A4, PPARG, and FASN in Met cows provided evidence that enhanced Met supply partly alleviated insulin resistance during the transition period. As such, 
the data suggest that adipose tissue in Met cows not only readily utilized glucose but also had the ability to accrete lipid via lipogenesis (Chinetti et al., 2000) even during a time when cows still experienced negative energy balance (Batistel et al., 2017b). Recent data underscored that the ability of adipose tissue for lipogenesis at 7 and $28 \mathrm{~d}$ postpartum is intact and responds to supply of acetate (Khan et al., 2013). Thus, the fact that cows fed Met also had greater rates of DMI postpartum agrees with the protein abundance data related to glucose utilization and lipogenesis.

The greater overall abundance of LIPE in Met-fed cows particularly after calving is noteworthy and would suggest a more pronounced degree of lipolysis (Khan et al., 2013; Locher et al., 2015). Whether differences in abundance of LIPE are a reflection of insulin sensitivity status is unclear. For instance, the greater prepartum DMI in cows fed Met (Batistel et al., 2017b) agrees with the lower LIPE abundance in those cows. In addition, differences in overall abundance between -10 and $10 \mathrm{~d}$ postpartum regardless of diet appeared modest. The sole study evaluating LIPE associations with loss of body mass early postpartum and insulin resistance detected no differences in abundance of this protein in spite of cows being classified as insulin resistant losing on average $89 \mathrm{~kg}$ of BW in the first $30 \mathrm{~d}$ postpartum (Zachut, 2015).

From a mechanistic standpoint, active lipolysis also encompasses re-esterification of fatty acids within adipose tissue (Duncan et al., 2007; Nye et al., 2008), a process that would require phosphoenolpyruvate carboxykinase 1 activity to generate glycerol-3-phosphate via glyceroneogenesis. The mRNA abundance of PCK1 in adipose tissue is greater in cows overfed energy prepartum and increases between wk 1 and 3 postpartum (Ji et al., 2012; Khan et al., 2013). Recent data indicated that in vitro basal lipolysis (measured via glycerol release) of tissue harvested at $-7,7$, and $28 \mathrm{~d}$ around parturition is similar (Khan et al., 2013). Furthermore, adipose tissue harvested at those times responded to the same degree to lipolytic stimuli (isoprotenerol) in vitro. Thus, simultaneous lipogenesis and lipolysis clearly are normal responses to the onset of lactation and respond to level of nutrient intake (i.e., greater protein abundance helps accommodate the greater nutrient supply available to adipose tissue; Sumner and McNamara, 2007). We believe the existence of these seemingly contrasting processes is a normal aspect of the remodeling process that adipose tissue undergoes during early lactation (McNamara et al., 1995).

Previous data from studies in humans underscored a potentially important role of systemic AA availability on the overall metabolism adipose tissue. Under fasting conditions, in vivo studies reported net uptake of Glu coupled with net release of Gln and Ala from human s.c. adipose tissue (Frayn et al., 1991). It was noteworthy that Ala uptake increased after a mixed meal when its concentrations in plasma rose. More recent data revealed that greater systemic AA availability in response to a meal increased AA transporter expression in human skeletal muscle at least in the short term $(3 \mathrm{~h}$ postfeeding; Drummond et al., 2010). Thus, it is likely that the systemic supply of AA could in part dictate their utilization by adipose.

Several transporters for AA across a wide-array of cell types have been identified. For instance, solute carrier family 38 member 1 (SLC38A1) uses a $\mathrm{Na}^{+}$gradient to concentrate neutral AA within cells (Mackenzie and Erickson, 2004). Solute carrier family 1 member 5 (SLC1A5) is a high-affinity, $\mathrm{Na}^{+}$-dependent transporter for Gln (Utsunomiya-Tate et al., 1996), and its inhibition blocks uptake of the AA and inhibits mTOR signaling (Nicklin et al., 2009). Solute carrier family 36 member 1 (SLC36A1) is a proton-coupled AA transporter localized specifically to lysosomes and exports AA from the lysosomal membrane to the cytosol where they can be used for protein synthesis (Zoncu et al., 2011). Solute carrier family 7 member 5 (SLC7A5) and SLC3A2 are bidirectional antiporters that regulate the exchange of intracellular Gln for extracellular Leu (Nicklin et al., 2009).

Because a previous study detected greater plasma concentrations of several essential and nonessential AA around parturition in response to feeding RPM (Zhou et al., 2016b), we speculate that the upregulation (mRNA and protein) of AA transporters in adipose tissue would be reflective of a greater degree of uptake from plasma. Clearly, systemic concentrations of AA around parturition would be driven in part by DMI and utilization by the mammary gland at the onset of lactation. Although plasma insulin concentrations were not affected by feeding Met, those cows had greater rates of DMI (Batistel et al., 2017b), milk yield, and milk protein content, suggesting additional AA in the circulation could very well have been utilized by peripheral tissues including adipose.

The greater overall mRNA and protein abundance of the membrane AA transporter SLC3A1 $\left(\mathrm{Na}^{+}-\right.$ independent), which transports neutral and basic AA, including the BCAA and Cys, in cows fed Met, agrees with the greater DMI and suggests enhanced capacity for utilization of AA. In fact, the gradual increase in abundance of SLC3A1 along with SLC1A5 $\left(\mathrm{Na}^{+}-\right.$ independent) and SLC38A1 (Na-coupled and saturable) from late pregnancy through $30 \mathrm{~d}$ postpartum regardless of diet underscores the ability of adipose tissue to utilize AA (neutral, basic, zwitterionic) even during a period of negative energy balance. In addition, 
because the protein abundance of BCKDK the ratelimiting enzyme for BCAA catabolism (Shimomura et al., 2001)] did not change between -10 and $10 \mathrm{~d}$ but increased at $30 \mathrm{~d}$ regardless of diet, we speculate that such response helps channel the utilization of BCAA from peripheral tissue to the mammary gland. Upregulation of SLC1A1, SLC1A5, SCL3A2, SLC36A1, and $S L C 38 A 1$ in cows fed Met supports their role in allowing for AA use by adipose tissue. In fact, data from nonruminant studies indicate that alterations in mRNA and protein abundance of AA transporters provide a link with intracellular activation of signaling pathways. For instance, mTOR activation is a powerful regulator of excitatory AA transporter 3 (SLC1A1; Almilaji et al., 2012). Thus, both mRNA and protein abundance of AA transporters and mTOR could potentially provide a link between DMI, systemic AA availability, and peripheral tissue utilization.

Activation of mTOR by AA leads to phosphorylation and inactivation of the repressor of mRNA translation eukaryotic initiation factor 4E-binding protein (EIF4EBP1), the phosphorylation and activation of S6 kinase (RPS6KB1), and the phosphorylation and activation of eukaryotic elongation factor 2 (EEF2), all of which increases rates of translation initiation and promotes the translocation step during elongation (Beugnet et al., 2003; Hay and Sonenberg, 2004; Wang and Proud, 2006; Kaul et al., 2011). Furthermore, activation of RPS6KB1 leads to phosphorylation of RPS6 and consequently regulates protein synthesis (Wullschleger et al., 2006). The fact that overall protein abundance of p-EIF4EBP1, p-RPS6, and p-EEF2 increased between $10 \mathrm{~d}$ prepartum and $30 \mathrm{~d}$ postpartum regardless of diet agrees with the pattern (mRNA, protein, or both) of most of the AA transporters measured. In part, this degree of concordance supports the idea that AA are readily utilized by adipose tissue during early lactation (despite negative energy balance). In addition, the marked upregulation of p-EIF4EBP1 ( 4.5fold) between -10 and $30 \mathrm{~d}$ also could be an indication that there is tight control of protein synthesis in adipose tissue in early lactation such that the priority for AA utilization still favors the mammary gland.

Based on the present and previous data, we could envision a situation in which the mammary gland has absolute priority over AA use in the early stages after calving, while over time and with the gradual increase in feed intake more AA become available for utilization by adipose tissue. Under such scenario, conditions that upregulate abundance of total mTOR and p-mTOR in adipose tissue might be the determining factor controlling AA use and the degree of protein synthesis. Although there is no evidence (to our knowledge) that an upregulation of AA transporters results in the activation of mTOR in adipose tissue, nonruminant data indicate that upregulation of placental AA transporters contributes to fetal growth via the activation of mTOR signaling (Jansson et al., 2013; Batistel et al., 2017a). Thus, AA availability and utilization by adipose tissue after calving may not only help in the remodeling process (McNamara et al., 1995) but also may serve ancillary functions such as preventing localized inflammation and oxidative stress (Chimin et al., 2017).

A limitation of the present study is that we did not evaluate adipocyte diameter, number, or volume, all of which are known to change during the transition period and early lactation (McNamara et al., 1995). Although diameter and volume decrease after parturition and remain below prepartal levels until at least $60 \mathrm{~d}$ postpartum, the number of adipocytes per gram of tissue actually increases (McNamara et al., 1995). The reduction in insulin sensitivity during the transition period, especially early lactation, has been well established (Bauman and Currie, 1980). Factors that cause this effect include the gradual reduction in DMI and the reduced sensitivity of the pancreas during lactation to insulinogenic signals (Lomax et al., 1979). Thus, such adaptations explain the decrease in lipid in adipose tissue especially during the first $30 \mathrm{~d}$ postpartum, and use of hyperinsulinemic-euglycemic clamps in early lactation have confirmed the potent antilipolytic effect of insulin (Corl et al., 2006).

In the present study, insulin concentration decreased after parturition, which is consistent with previous reports (De Koster et al., 2018) indicating lipolysis was favored in the postpartum. Despite that, FASN and PPARG (key contributors to lipogenesis/adipogenesis) had the highest abundance at d 30, likely as a result of the gradual increase in DMI after parturition (Batistel et al., 2017b). During the transition period, a greater BW loss postpartum is associated with impaired insulin signaling in adipose tissue (Zachut et al., 2013). In mice, a deficiency of mTOR in adipocytes induces localized inflammation by promoting oxidative stress (Chimin et al., 2017). Thus, the fact that the lowest abundance of p-AKT and p-mTOR was detected at d 10 underscores the risk that cows face immediately postpartum for developing metabolic disorders related to adipose tissue function. Although not studied in ruminants, insulin can contribute to protein synthesis in adipose tissue of rodents (Krahl, 1964). Based on the present data, it is possible that the decrease in insulin after parturition also contributes to lower p-mTOR. Overall, the results indicate that mTOR and insulin signaling pathways in adipose tissue adapt to the change in physiologic state during the periparturient period. 


\section{CONCLUSIONS}

Protein abundance of various components of insulin and mTOR signaling pathways in adipose tissue adjust to the onset of lactation. Upregulation of mRNA and protein abundance of some AA transporters along with greater abundance of $\mathrm{p}-\mathrm{AKT}$ and $\mathrm{p}-\mathrm{mTOR}$ in response to supply of Met suggests a mechanistic link. Thus, at least from a transcription and translation level, insulin and mTOR signaling pathways seem responsive to DMI and the systemic availability of key nutrients including glucose, AA, and lipogenic substrates. Although the pattern of protein abundance of key proteins driving utilization of nutrients right after parturition seems to indicate a priority by the mammary gland, toward the end of the transition period the data indicate that adipose tissue is capable of readily utilizing nutrients without competing with the mammary gland. The exact molecular mechanisms linking nutrition of the periparturient cow with mTOR signaling and AA metabolism by adipose tissue merits further study.

\section{ACKNOWLEDGMENTS}

Y. Liang is a recipient of a doctoral fellowship from China Scholarship Council (Beijing, China). F. Batistel was supported by a fellowship from Coordenação de Aperfeiçoamento de Pessoal de Nível Superior (Brazilian Ministry of Education, Brasília, Brazil) and by Hatch funds under project ILLU-538-914, National Institute of Food and Agriculture (Washington, DC).

\section{REFERENCES}

Almilaji, A., T. Pakladok, A. Guo, C. Munoz, M. Föller, and F. Lang. 2012. Regulation of the glutamate transporter EAAT3 by mammalian target of rapamycin mTOR. Biochem. Biophys. Res. Commun. 421:159-163.

Badoud, F., K. P. Lam, A. DiBattista, M. Perreault, M. A. Zulyniak, B. Cattrysse, S. Stephenson, P. Britz-McKibbin, and D. M. Mutch. 2014. Serum and adipose tissue amino acid homeostasis in the metabolically healthy obese. J. Proteome Res. 13:3455-3466.

Batistel, F., A. S. Alharthi, L. Wang, C. Parys, Y.-X. Pan, F. C. Cardoso, and J. J. Loor. 2017a. Placentome nutrient transporters and mammalian target of rapamycin signaling proteins are altered by the methionine supply during late gestation in dairy cows and are associated with newborn birth weight. J. Nutr. 147:1640-1647.

Batistel, F., J. Arroyo, A. Bellingeri, L. Wang, B. Saremi, C. Parys, E. Trevisi, F. Cardoso, and J. Loor. 2017b. Ethyl-cellulose rumenprotected methionine enhances performance during the periparturient period and early lactation in Holstein dairy cows. J. Dairy Sci. 100:7455-7467.

Batistel, F., J. Arroyo, C. Garces, E. Trevisi, C. Parys, M. Ballou, F. Cardoso, and J. Loor. 2018. Ethyl-cellulose rumen-protected methionine alleviates inflammation and oxidative stress and improves neutrophil function during the periparturient period and early lactation in Holstein dairy cows. J. Dairy Sci. 101:480-490.

Bauman, D. E., and W. B. Currie. 1980. Partitioning of nutrients during pregnancy and lactation: A review of mechanisms involving homeostasis and homeorhesis. J. Dairy Sci. 63:1514-1529.
Bell, A. W., and D. E. Bauman. 1997. Adaptations of glucose metabolism during pregnancy and lactation. J. Mammary Gland Biol. Neoplasia 2:265-278.

Beugnet, A., A. R. Tee, P. M. Taylor, and C. G. Proud. 2003. Regulation of targets of mTOR (mammalian target of rapamycin) signalling by intracellular amino acid availability. Biochem. J. 372:555.

Cardoso, F. C., W. Sears, S. J. LeBlanc, and J. K. Drackley. 2011. Technical note: Comparison of 3 methods for analyzing areas under the curve for glucose and nonesterified fatty acids concentrations following epinephrine challenge in dairy cows. J. Dairy Sci. 94:6111-6115. https://doi.org/10.3168/jds.2011-4627.

Chimin, P., M. L. Andrade, T. Belchior, V. A. Paschoal, J. Magdalon, A. S. Yamashita, É. Castro, A. Castoldi, A. B. Chaves-Filho, and M. Y. Yoshinaga. 2017. Adipocyte mTORC1 deficiency promotes adipose tissue inflammation and NLRP3 inflammasome activation via oxidative stress and de novo ceramide synthesis. J. Lipid Res. 58:1797-1807.

Chinetti, G., J.-C. Fruchart, and B. Staels. 2000. Peroxisome proliferator-activated receptors (PPARs): Nuclear receptors at the crossroads between lipid metabolism and inflammation. Inflamm. Res. 49:497-505.

Corl, B., S. Butler, W. Butler, and D. Bauman. 2006. Regulation of milk fat yield and fatty acid composition by insulin. J. Dairy Sci. 89:4172-4175.

De Koster, J., R. K. Nelli, C. Strieder-Barboza, J. de Souza, A. L. Lock, and G. A. Contreras. 2018. The contribution of hormone sensitive lipase to adipose tissue lipolysis and its regulation by insulin in periparturient dairy cows. Sci. Rep. 8:13378.

De Koster, J. D., and G. Opsomer. 2013. Insulin resistance in dairy cows. Vet. Clin. North Am. Food Anim. Pract. 29:299-322.

Drummond, M. J., E. L. Glynn, C. S. Fry, K. L. Timmerman, E. Volpi, and B. B. Rasmussen. 2010. An increase in essential amino acid availability upregulates amino acid transporter expression in human skeletal muscle. Am. J. Physiol. Endocrinol. Metab. 298:E1011-E1018.

Duncan, R. E., M. Ahmadian, K. Jaworski, E. Sarkadi-Nagy, and H. S. Sul. 2007. Regulation of lipolysis in adipocytes. Annu. Rev. Nutr. 27:79-101.

Feller, D., and E. Feist. 1963. Conversion of methionine and threonine to fatty acids by adipose tissue. Can. J. Biochem. Physiol. 41:269-273.

Frayn, K., K. Khan, S. Coppack, and M. Elia. 1991. Amino acid metabolism in human subcutaneous adipose tissue in vivo. Clin. Sci. (Lond.) 80:471-474.

Hay, N., and N. Sonenberg. 2004. Upstream and downstream of mTOR. Genes Dev. 18:1926-1945.

Herman, M. A., P. She, O. D. Peroni, C. J. Lynch, and B. B. Kahn. 2010. Adipose tissue branched-chain amino acid (BCAA) metabolism modulates circulating BCAA levels. J. Biol. Chem. 285:11348-11356.

Jansson, N., F. J. Rosario, F. Gaccioli, S. Lager, H. N. Jones, S. Roos, T. Jansson, and T. L. Powell. 2013. Activation of placental mTOR signaling and amino acid transporters in obese women giving birth to large babies. J. Clin. Endocrinol. Metab. 98:105-113.

Ji, P., J. Osorio, J. Drackley, and J. Loor. 2012. Overfeeding a moderate energy diet prepartum does not impair bovine subcutaneous adipose tissue insulin signal transduction and induces marked changes in peripartal gene network expression. J. Dairy Sci. 95:4333-4351.

Kaul, G., G. Pattan, and T. Rafeequi. 2011. Eukaryotic elongation factor-2 (eEF2): Its regulation and peptide chain elongation. Cell Biochem. Funct. 29:227-234.

Khan, M., A. Hosseini, S. Burrell, S. Rocco, J. McNamara, and J. Loor. 2013. Change in subcutaneous adipose tissue metabolism and gene network expression during the transition period in dairy cows, including differences due to sire genetic merit. J. Dairy Sci. 96:2171-2182.

Krahl, M. E. 1964. Stimulation of peptide synthesis in adipose tissue by insulin without glucose. Am. J. Physiol. 206:618-620.

Locher, L., S. Häussler, L. Laubenthal, S. Singh, J. Winkler, A. Kinoshita, Á. Kenéz, J. Rehage, K. Huber, and H. Sauerwein. 2015. Effect of increasing body condition on key regulators of fat 
metabolism in subcutaneous adipose tissue depot and circulation of nonlactating dairy cows. J. Dairy Sci. 98:1057-1068.

Lomax, M. A., G. D. Baird, C. B. Mallinson, and H. Symonds. 1979. Differences between lactating and non-lactating dairy cows in concentration and secretion rate of insulin. Biochem. J. 180:281-289.

Loor, J. J., M. Bionaz, and J. K. Drackley. 2013. Systems physiology in dairy cattle: Nutritional genomics and beyond. Annu. Rev. Anim. Biosci. 1:365-392. https://doi.org/10.1146/annurev-animal $-031412-103728$.

Lu, J., G. Xie, W. Jia, and W. Jia. 2013. Insulin resistance and the metabolism of branched-chain amino acids. Front. Med. 7:53-59.

Lynch, C. J., and S. H. Adams. 2014. Branched-chain amino acids in metabolic signalling and insulin resistance. Nat. Rev. Endocrinol. 10:723-736.

Mackenzie, B., and J. D. Erickson. 2004. Sodium-coupled neutral amino acid (System N/A) transporters of the SLC38 gene family. Pflugers Arch. 447:784-795.

McCormack, S. E., O. Shaham, M. A. McCarthy, A. A. Deik, T. J. Wang, R. E. Gerszten, C. B. Clish, V. K. Mootha, S. K. Grinspoon, and A. Fleischman. 2013. Circulating branched-chain amino acid concentrations are associated with obesity and future insulin resistance in children and adolescents. Pediatr. Obes. 8:52-61.

McNamara, J. P., J. Harrison, R. Kincaid, and S. Waltner. 1995. Lipid metabolism in adipose tissue of cows fed high fat diets during lactation. J. Dairy Sci. 78:2782-2796.

NRC. 2001. Nutrient Requirements of Dairy Cattle. 7th rev. ed. Natl. Acad. Press, Washington, DC.

Newgard, C. B., J. An, J. R. Bain, M. J. Muehlbauer, R. D. Stevens, L. F. Lien, A. M. Haqq, S. H. Shah, M. Arlotto, and C. A. Slentz. 2009. A branched-chain amino acid-related metabolic signature that differentiates obese and lean humans and contributes to insulin resistance. Cell Metab. 9:311-326.

Nicklin, P., P. Bergman, B. Zhang, E. Triantafellow, H. Wang, B. Nyfeler, H. Yang, M. Hild, C. Kung, and C. Wilson. 2009. Bidirectional transport of amino acids regulates mTOR and autophagy. Cell 136:521-534.

Nye, C., J. Kim, S. C. Kalhan, and R. W. Hanson. 2008. Reassessing triglyceride synthesis in adipose tissue. Trends Endocrinol. Metab. 19:356-361.

Osorio, J. S., P. Ji, J. K. Drackley, D. Luchini, and J. J. Loor. 2014a. Smartamine $\mathrm{M}$ and MetaSmart supplementation during the peripartal period alter hepatic expression of gene networks in 1-carbon metabolism, inflammation, oxidative stress, and the growth hormone-insulin-like growth factor 1 axis pathways. J. Dairy Sci. 97:7451-7464.

Osorio, J. S., E. Trevisi, P. Ji, J. Drackley, D. Luchini, G. Bertoni, and J. Loor. 2014b. Biomarkers of inflammation, metabolism, and oxidative stress in blood, liver, and milk reveal a better immunometabolic status in peripartal cows supplemented with Smartamine M or MetaSmart. J. Dairy Sci. 97:7437-7450.

Pessin, J. E., and A. R. Saltiel. 2000. Signaling pathways in insulin action: Molecular targets of insulin resistance. J. Clin. Invest. 106:165-169.

Phillips, G. J., T. Citron, J. Sage, K. Cummins, M. Cecava, and J. McNamara. 2003. Adaptations in body muscle and fat in transition dairy cattle fed differing amounts of protein and methionine hydroxy analog. J. Dairy Sci. 86:3634-3647.

Schwab, C. G., and G. A. Broderick. 2017. A 100-Year Review: Protein and amino acid nutrition in dairy cows. J. Dairy Sci. 100:1009410112.

Shimomura, Y., M. Obayashi, T. Murakami, and R. A. Harris. 2001. Regulation of branched-chain amino acid catabolism: Nutritional and hormonal regulation of activity and expression of the branched-chain $\alpha$-keto acid dehydrogenase kinase. Curr. Opin. Clin. Nutr. Metab. Care 4:419-423.

Sordillo, L. M., and W. Raphael. 2013. Significance of metabolic stress, lipid mobilization, and inflammation on transition cow disorders. Vet. Clin. North Am. Food Anim. Pract. 29:267-278.

Sumner, J. M., and J. McNamara. 2007. Expression of lipolytic genes in the adipose tissue of pregnant and lactating Holstein dairy cattle. J. Dairy Sci. 90:5237-5246.

Utsunomiya-Tate, N., H. Endou, and Y. Kanai. 1996. Cloning and functional characterization of a system ASC-like Na+-dependent neutral amino acid transporter. J. Biol. Chem. 271:14883-14890.

Vailati-Riboni, M., G. Farina, F. Batistel, A. Heiser, M. Mitchell, M. Crookenden, C. Walker, J. Kay, S. Meier, and J. Roche. 2017. Far-off and close-up dry matter intake modulate indicators of immunometabolic adaptations to lactation in subcutaneous adipose tissue of pasture-based transition dairy cows. J. Dairy Sci. 100:2334-2350.

Vailati-Riboni, M., M. Kanwal, O. Bulgari, S. Meier, N. Priest, C. Burke, J. Kay, S. McDougall, M. Mitchell, and C. Walker. 2016. Body condition score and plane of nutrition prepartum affect adipose tissue transcriptome regulators of metabolism and inflammation in grazing dairy cows during the transition period. J. Dairy Sci. 99:758-770.

Vailati-Riboni, M., S. Meier, N. Priest, C. Burke, J. Kay, S. McDougall, M. Mitchell, C. Walker, M. Crookenden, and A. Heiser. 2015. Adipose and liver gene expression profiles in response to treatment with a nonsteroidal antiinflammatory drug after calving in grazing dairy cows. J. Dairy Sci. 98:3079-3085.

Wang, X., and C. G. Proud. 2006. The mTOR pathway in the control of protein synthesis. Physiology (Bethesda) 21:362-369.

Wullschleger, S., R. Loewith, and M. N. Hall. 2006. TOR signaling in growth and metabolism. Cell 124:471-484.

Zachut, M. 2015. Defining the adipose tissue proteome of dairy cows to reveal biomarkers related to peripartum insulin resistance and metabolic status. J. Proteome Res. 14:2863-2871.

Zachut, M., H. Honig, S. Striem, Y. Zick, S. Boura-Halfon, and U. Moallem. 2013. Periparturient dairy cows do not exhibit hepatic insulin resistance, yet adipose-specific insulin resistance occurs in cows prone to high weight loss. J. Dairy Sci. 96:5656-5669.

Zhai, W., C. Xu, Y. Ling, S. Liu, J. Deng, Y. Qi, C. Londos, and G $\mathrm{Xu}$. 2010. Increased lipolysis in adipose tissues is associated with elevation of systemic free fatty acids and insulin resistance in perilipin null mice. Horm. Metab. Res. 42:247-253.

Zhou, Z., O. Bulgari, M. Vailati-Riboni, E. Trevisi, M. A. Ballou, F. C. Cardoso, D. N. Luchini, and J. J. Loor. 2016a. Rumen-protected methionine compared with rumen-protected choline improves immunometabolic status in dairy cows during the peripartal period. J. Dairy Sci. 99:8956-8969. https://doi.org/10.3168/jds.2016 $-10986$.

Zhou, Z., F. Ferdous, P. Montagner, D. Luchini, M. Corrêa, and J. Loor. 2018. Methionine and choline supply during the peripartal period alter polymorphonuclear leukocyte immune response and immunometabolic gene expression in Holstein cows. J. Dairy Sci. 101:10374-10382.

Zhou, Z., M. Vailati-Riboni, D. N. Luchini, and J. J. Loor. 2016b. Methionine and choline supply during the periparturient period alter plasma amino acid and one-carbon metabolism profiles to various extents: Potential role in hepatic metabolism and antioxidant status. Nutrients 9:10.

Zoncu, R., L. Bar-Peled, A. Efeyan, S. Wang, Y. Sancak, and D. M. Sabatini. 2011. mTORC1 senses lysosomal amino acids through an inside-out mechanism that requires the vacuolar H+-ATPase. Science 334:678-683 